\title{
Chapter 7 \\ The Association Between Self-Reported Health Problems and Household Prosperity
}

\author{
Maurizia Masia, Monica Budowski, and Robin Tillmann
}

\section{Introduction}

This chapter focuses on the relationship between individual health and its financial effects on the household in Switzerland in terms of its welfare, a topic which to date has been rarely explored scientifically. Given the widely documented national and international research findings on the association between social inequality and health, this topic warrants attention. Two major explanatory models have emerged in the social science debates about health inequalities on the individual level: the causality hypothesis and the selection hypothesis. The causality hypothesis has a long tradition of research, revealing that higher socioeconomic status leads to better health and, conversely, lower socioeconomic status to worse health. It has repeatedly been confirmed that socioeconomic factors such as income, education, and social status affect health (e.g. Allanson et al. 2010). International findings have also made clear that the effect of socioeconomic factors on health is not countrydependent. In Europe, in Australia, Canada, and the US, mortality rates are highest for people with lower occupational status, lower educational levels, and lower incomes (Mackenbach 2006). Longitudinal analyses have provided information about the long-term effects of socioeconomic factors on health and studied the selection effect of health (Dragano and Siegrist 2009; Rueda et al. 2012). Selection in this context refers to the process of social mobility: as the likelihood of upward

\footnotetext{
M. Masia $(\bowtie) \cdot$ M. Budowski

Division of Sociology, Social Policy and Social Work, Department of Social Sciences,

University of Fribourg, Fribourg, Switzerland

e-mail: maurizia.masia@unifr.ch; monica.budowski@unifr.ch

R. Tillmann

FORS-Swiss Centre of Expertise in the Social Sciences, Lausanne, Switzerland

e-mail: robin.tillmann@fors.unil.ch
} 
social mobility is greater for healthy people, there is a higher risk of social decline for those who are sick (Connolly et al. 2007).

From a life course perspective and focusing on individuals, the existence of health-related selection processes is undisputed. Epidemiological and health inequality research has explored and discussed both causal and selective health mechanisms, which are not thought to be mutually exclusive. Nevertheless, the causal hypothesis with its focus on individuals has continued to receive more attention in research and thus overshadowed research both on health selection mechanisms and the consequences of ill health beyond individual circumstances. Research in countries of the Global North has neither paid sufficient attention to the consequences of a household member's ill health for the household's welfare and social mobility nor for other household members. ${ }^{1}$

In this contribution, we ask whether the household's welfare, i.e., material wellbeing, is affected when a household member's health deteriorates. Deterioration in health is a complex phenomenon that cannot be defined solely according to the dichotomy of "healthy" vs. "sick" (Erhart et al. 2009). From an individual and subjective perspective, the experience of being healthy or sick is certainly important. Therefore, the subjective perception of well-being reflects whether a person feels ill or healthy; this perception may change between points in time on a temporal continuum over the life course. Ill health may be interpreted as a phase of imbalance between risks and protective factors occurring when an individual lacks the physical and/or mental resources to cope with the various requirements of everyday life (Hurrelmann 2006). The onset of ill health may also be understood as a critical life event that disrupts individuals' normal contexts of activity requiring adaptions for everyday activities (Filipp and Aymanns 2009).

With this in mind, we ask whether and to what extent the onset of a member's illhealth affects his or her household's welfare, when this member's function is that of a breadwinner. The "breadwinner" refers to the "sole-earner" in a household or to a "co-earner" contributing a substantial proportion to household income. Household members with no substantial contribution to the household income ("secondary earners") are not considered breadwinners. Analytically, we focus on sole-earner households. In sole-earner households one member takes over the breadwinner role and secures household income, whereas in multiple-earner households various household members as co-earners each contribute substantially and share the function of the breadwinner to secure household income together. When combining the resource and the deprivation approach, welfare, i.e., material well-being, may be understood as the result of different living standards and income situations (Townsend 1979). For our analysis, we concentrate on the changes over time in three "welfare positions" ("prosperity", "precariousness", and "poverty"). The dynamic relationship between the deterioration of breadwinner's health for the household and the household's welfare may be considered a function of the demographic, resource-specific, and psy-

\footnotetext{
${ }^{1}$ There is, however, an ongoing debate and research in countries of the Global South for example with regards to "catastrophic health expenditures" and the economic burden of illnesses for household and their strategies.
} 
chosocial characteristics of households when comparing the situation before and after the deterioration of the breadwinner's health. The Swiss Household Panel (SHP) provides the data for our empirical analysis.

\section{Health and Welfare in the Household: A Theoretical Framework}

A private household may, in general, be classified as belonging to an individual's everyday experience. Private households as units of analysis may include one or many individuals. Multi-person households may be differentiated into couple households with or without children, households with single parents and children, and others. A functional household's constitutive characteristics are that to provide material and immaterial services to meet the household members' welfare-relevant needs and goals, and that some activities and expenditures are shared (Casimir and Tobi 2011; Egner 1976).

The resource approach emphasizes economic aspects and the extent to which individual household members take on a provider status. The relative amount of income that each person contributes to the household determines the provider status (Blood and Wolfe 1960). The breadwinning function of household members may be distinguished according to the following categories: "sole-earner", "co-earner", or a member who contributes no (substantial) income, a "secondary earner". If the breadwinner function relies on one person, households are considered to be "soleearner households"; if this function is shared by more co-earning household members substantially contributing to household income, they constitute "multiple-earner households". It may be argued that the household's welfare goes beyond economic terms and also depends on the emotional and symbolic tasks that household members take over (albeit generally unequally distributed) on the basis of solidarity amongst the household members (Galler and Ott 1993). Household organization, thus, depends the distribution of income generation, unpaid housekeeping and caregiving. The latter are, when necessary, still performed in the majority of cases by women in the household (Daly 2011; Budowski et al. 2016). Moreover, to better understand how households allocate income generation for the household and its usage, it is relevant to consider not only tangible but also intangible resources, such as education, health, and social support (Thébaud 2010). Household members mobilize their personal, social, and economic potential and organize their work in order to ensure the provision of welfare-relevant contributions to the household (e.g., prosperity, health, or prestige).

Adopting the life course perspective as a "status biography" (Levy 1996), the individual life courses of household members may be considered both as products of employment and income-specific configurations, and as contingent on the household's standard of living and welfare. The position and role structures within the household shape its welfare over time and, depending on social conditions, are associated with different capacities and limitations for the members to achieve desired 
objectives. As we focus on the function of the breadwinner within the household, we conceptualize the onset of his or her health deterioration as a critical event that may interfere with routine activities and affect the household's welfare (Filipp and Aymanns 2009). Such an event may influence the way the household is organized, for example, the household members' division of labor. Daily activities are expected to change both for the person with ill-health and for the other household members and to be contingent on the household situation. Coping strategies may be required, for example, to deal with the consequences of the breadwinner's ill-health-related inability to work (and particularly income-loss) that may lead to material burdens.

\section{Hypotheses}

From a life course perspective, a deterioration in a breadwinner's health may be conceptualized as a critical event that causes an interruption of familiar and everyday household procedures (Filipp and Aymanns 2009). Following this line of argument, it is reasonable to expect that the effects of a breadwinner's deterioration in health depends both on the severity of his or her health conditions and on his or her provisioning function, i.e., the positions and role structure within the household. These elements should contribute to explaining an enhanced risk of decline in household welfare. The first hypothesis therefore makes explicit the relationship between the deterioration of the breadwinner's health (sole-earner or co-earner), use of healthcare services, and the risk of change to a less favorable welfare position:

$\mathrm{H}_{1}$ : As a result of a breadwinner's chronic, mental and physical illness and his or her increased use of healthcare services, the risk of descent in household welfare position is likely to augment.

The impact of a breadwinner's health deterioration on household welfare position needs to be understood in light of household-dependent factors. Research into poverty and inequality has shown that sociodemographic factors play a key role in explaining deprivation and income in the household (Callens and Croux 2009; Halleröd and Gustafsson 2011). Whereas a greater number of children living in the household is associated with an increased risk of poverty, a greater number of adults is associated with additional income potential in the household (Jenkins 2000). Thus, apart from the breadwinner's deterioration in health, sociodemographic factors influence the household's welfare leading to hypotheses $\mathrm{H}_{2}$ and $\mathrm{H}_{3}$ :

$\mathrm{H}_{2}$ : If more adults live in the household prior to the deterioration of the breadwinner's health, the risk of descent in household welfare position is likely to diminish.

$\mathrm{H}_{3}$ : If more children live in the household prior to the deterioration of the breadwinner's health, the risk of descent in household welfare position is likely to augment.

The household is a dynamic unit over time. From the perspective of different points in time and at the household level, some studies have provided evidence that 
demographic processes (e.g., the birth of a baby, the departure of a household member) or critical events (e.g., divorce, death) impact on household income (Chen and Korinek 2010; Jenkins 2000; Sauerborn et al. 1996). Thus, hypothesis $\left(\mathrm{H}_{4}\right)$ is:

$\mathrm{H}_{4}$ : An increase in the number of adults in a household (when compared to before the deterioration of the breadwinner's health) reduces the risk of descent in household welfare position as a result of the deterioration of the breadwinner's health.

Considering the importance of cumulative disadvantages, it is probable that an accumulation of psychosocial strain affects the behavior of household members after the deterioration of a breadwinner's health (Jungbauer-Gans and Gross 2009; Steinkamp 1999). These stressful events may reflect in behavior-specific risk factors affecting the household members' coping strategies, thereby making it more difficult to achieve material security. Therefore, we put forth the following hypotheses $\left(\mathrm{H}_{5}\right.$ and $\left.\mathrm{H}_{6}\right)$ :

$\mathrm{H}_{5}$ : The higher the level of psychosocial strain in the household before the deterioration of the breadwinner's health, the more likely will be a descent in household welfare position.

$\mathrm{H}_{6}$ : The greater the number of chronically ill people living in the household prior to the deterioration of the breadwinner's health, the greater the risk of a descent in household welfare position.

Considering cumulative disadvantages and advantages, we assume that the household may reorganize itself after the deterioration of the breadwinner's health. This reorganization need not be interpreted in terms of risk only, but may also be done in terms of favorable or risk-reducing resources (Keck and Sakdapolrak 2013). Household members' individual characteristics and their social relationships may work as protective factors. Therefore, the resource-specific configuration of the household (e.g., education, health, and social support) may buffer the risks of descent in household welfare after the deterioration of the breadwinner's health. Hypothesis 7 states this relationship:

$\mathrm{H}_{7}$ : Higher intangible resources (highest level of education, average health, average social support) within the household prior to the deterioration of the breadwinner's health are likely to protect against a descent of the household's welfare position.

Based on the accumulation model, and adopting a dynamic perspective on the household, we expect that a deterioration of the breadwinner's health will lead to an accumulation of psychosocial strain in the household. The risks to household welfare may therefore intensify, so that a decline of the household's welfare position becomes more likely. In contrast, the event may also lead to a change in employment status of other household members. If there is a potential for additional income, the risk that the household welfare position declines may be reduced. The compensatory possibilities offered by other members in the household become more important. This results in the following two hypotheses $\left(\mathrm{H}_{8}, \mathrm{H}_{9}\right)$ : 
$\mathrm{H}_{8}$ : Greater psychosocial strain in the household as a result of the deterioration of the breadwinner's health increases the risk of descent in household welfare position.

$\mathrm{H}_{9}$ : An increase in the workload of all adults in the household as a result of the deterioration of the breadwinner's health reduces the risk of descent in household welfare position.

\section{Methodological Issues and Operationalization}

The empirical test of our hypotheses is based on data from the first 16 waves of the Swiss Household Panel (SHP, 1999-2014). The SHP contains a large range of variables related to the household, such as living conditions, standard of living, and certain activities. It also contains a large array of information about individual household members (e.g., health status, life events, occupation, education, employment level, occupational prestige, health, etc.).

In order to analyze how the household's welfare position is affected by a household's breadwinner's deterioration of health, we employ data from the entire panel for all household members who had suffered a deterioration in (self-reported) health. All households were included in the analyses, in which one household member aged 18 to 64 years had suffered a deterioration of health within a time frame of four years (single person households were excluded). A deterioration of health was defined to have occurred when a household member experienced a (subjective) deterioration of health (i.e., when interviewees answered with point 4 or less on an 11-point scale regarding the question: "In the last 12 months, has your health improved or worsened, if 0 means "greatly worsened" and 10 "greatly improved") and when his or her health status remained unchanged for two further years thereafter. The longitudinal data were pooled at the time point at which (subjective) health deteriorated. Hence, the results are not interpreted per calendar year, but in relation to the onset of the household member's deterioration in health. Data were available one year before the point in time health deteriorated $\left(t_{-1}\right)$, in the year in which health deteriorated $\left(t_{0}\right)$, and for the two following years. A before/after comparison (from $t_{-1}$ to $t_{0}$ ) was conducted in order to perform an inferential statistical analysis of the change in household welfare position. In the SHP data (1999-2014), 859 persons experienced a deterioration of health within a four-year time frame as described above.

As is commonly known, poverty rates fluctuate considerably according to how income poverty thresholds are defined. In the Swiss case, previous research has shown that poverty rates fluctuate from about 6 to $23 \%$ for the years 1999 to 2003 , depending on the selected income level $(50,60$, or $70 \%$ of the median) (Tillmann and Budowski 2006). This kind of poverty threshold represents an indirect poverty measure because it is based on income. Direct measures of poverty include household expenditures or fulfilling certain criteria that correspond to an "acceptable standard of living" in a given context (Townsend 1979). According to Gordon and Spicker (1999), the direct measure of an "acceptable standard of living" is consid- 
ered superior to the expenditure approach. Following Townsend's studies, we conceptualize poverty with a measure that integrates income, and possession of goods and opportunities for activities and services. The monetary poverty threshold is set at $60 \%$ of the median equivalized household income. Deprivation consists of the lack of goods (e.g., a car, a washing machine, a dishwasher, or a computer) or activities or services (e.g., eat at a restaurant at least once a month, take a week's holiday away from home each year, save money in a private pension fund, or invite friends to the household at least once a month) due to financial reasons that a majority of households in Switzerland does not lack.

We combined these two aspects (income and deprivation) to construct three welfare positions. The first household welfare position is defined by non-poverty; for reasons of comprehensibility we refer to it as "prosperity". The second household welfare position is defined as "precarious": the household is deprived in two or more items yet avails an income level above the poverty threshold or, alternatively, the household with an income level below the poverty threshold yet is deprived at most in one item. The third welfare position is defined as consistently "poor" (an income level below the poverty threshold and deprived in two or more items).

The effects of the deterioration of the breadwinner's health are considered in terms of his or her household's movements across these different welfare positions (prosperity, precariousness, and poverty). To compare the welfare position before and after the deterioration of the breadwinner's health (i.e., from $t_{-1}$ to $t_{0}$ ), we created a dependent variable capturing the household's movement. Households remaining at the same welfare position before the deterioration of the breadwinner's health $\left(\mathrm{t}_{-1}\right)$ and after it $\left(\mathrm{t}_{0}\right)$ are considered "stable". Households changing their welfare position (from $t_{-1}$ to $t_{0}$ ) are considered either to ascend (i.e. be "upwardly mobile") or to descend in welfare position (i.e. be "downwardly mobile"). The operationalized independent variables included in the analysis model are shown in Table 7.1.

\section{Results}

\section{The Development of Health-Related Factors}

To empirically ground the perceived deterioration of health as a critical life event, we examined how various health-related variables, for example, physical and psychological health problems and the use of healthcare services changed in the course of the defined time period (four subsequent years). To compare the changes in different health-related variables we present the percentage change in health over time (see Fig. 7.1).

Figure 7.1 shows a clear pattern of change emerging regarding (physical and psychological) health problems and the use of healthcare services accompanying the subjectively perceived deterioration in health. The rates increase for all three indicators by more than 5\%. Although the health care system is utilized more intensively after the onset of ill-health $\left(t_{0}\right)$, the level of use a year later $\left(t_{1}\right)$ is practi- 
Table 7.1 Operationalization of the independent variables

\begin{tabular}{|c|c|}
\hline Health factors & $\begin{array}{l}\text { These factors capture three different aspects of the breadwinner's health: } \\
\text { physical and psychological health and use of healthcare services. The three } \\
\text { health indicators were extracted by means of an exploratory factor analysis from } \\
\text { nine items available in the SHP. The ranges of values ( } \min / \mathrm{max} \text { ) of these three } \\
\text { factors are: }-4.74 / 6.56 \text { (psychological strain), }-7.06 / 6.88 \text { (physical problems), } \\
-3.58 / 4.95 \text { (use of health care services). }\end{array}$ \\
\hline $\begin{array}{l}\text { Number of } \\
\text { adults }\end{array}$ & Number of adults in the household \\
\hline $\begin{array}{l}\text { Number of } \\
\text { children }\end{array}$ & Number of children (up to age 17) in the household \\
\hline $\begin{array}{l}\text { Psychosocial } \\
\text { strain }\end{array}$ & $\begin{array}{l}\text { For each adult member of the household the summative index "number of } \\
\text { psychosocial strain" calculates the number of strains and captures the amount of } \\
\text { strains that all adult household members reported on the household level (e.g., } \\
\text { problems with their own children, conflicts with a close relationship, the break, } \\
\text { illness or the death of a close relationship). Alongside the mean number of } \\
\text { psychosocial strains within a household, the mean intensity of the strain for the } \\
\text { household is calculated as the arithmetic mean of all scores as a household } \\
\text { characteristic. The survey collects the information on the subjective rating of } \\
\text { each strain on a Likert scale ranging from } 0 \text { "not at all burdened by strain" to } 10 \\
\text { "completely burdened by strain". }\end{array}$ \\
\hline $\begin{array}{l}\text { Number of } \\
\text { chronic } \\
\text { illnesses }\end{array}$ & Number of people with chronic illnesses in the household \\
\hline $\begin{array}{l}\text { Highest } \\
\text { education } \\
\text { level }\end{array}$ & $\begin{array}{l}\text { Highest education level represented in the household (adults only), converted } \\
\text { into the number of years of education; values range from } 0 \text { (no schooling) to } 21 \\
\text { (PhD-degree) }\end{array}$ \\
\hline Health & $\begin{array}{l}\text { The mean health of all adult household members; subjective ratings on a Likert } \\
\text { scale ranging from } 1 \text { "very poor" to } 5 \text { "very good" }\end{array}$ \\
\hline $\begin{array}{l}\text { Mean social } \\
\text { support }\end{array}$ & $\begin{array}{l}\text { For each adult member of the household the summative index "social support" } \\
\text { describes the practical and emotional support received from partners, relatives, } \\
\text { neighbors and friends. The mean social support is the arithmetic mean of all } \\
\text { scores as a household characteristic (scale: } 0-10 \text { points). }\end{array}$ \\
\hline $\begin{array}{l}\text { Total } \\
\text { employment } \\
\text { load }\end{array}$ & $\begin{array}{l}\text { Accumulated work load of all adult household members. In our dataset, the total } \\
\text { employment load after a deterioration of breadwinner's health varied from }-200 \\
\text { to }+200 \text { (this corresponds to }+/-2 \text { fulltime jobs in the household). }\end{array}$ \\
\hline
\end{tabular}

cally the same again as it was before the onset $\left(\mathrm{t}_{-1}\right)$. Physical health problems show a similar pattern of change, whereby the increase in physical health problems after the initial deterioration of health is not significant. In contrast, psychological strain increases more strongly and then decreases gradually over time. Thus, subjectively perceived deterioration of health shows different effects over time, whereby it may be assumed that the effect of this life event is health-specific. Based on these considerations, we now focus on the household and, more specifically, address the topic of how a breadwinner's deterioration of health particularly affects the household's welfare. The regression analysis allows for generating more detailed information about the relevance of the breadwinner's deterioration of health with respect to a change in the household's welfare position. 


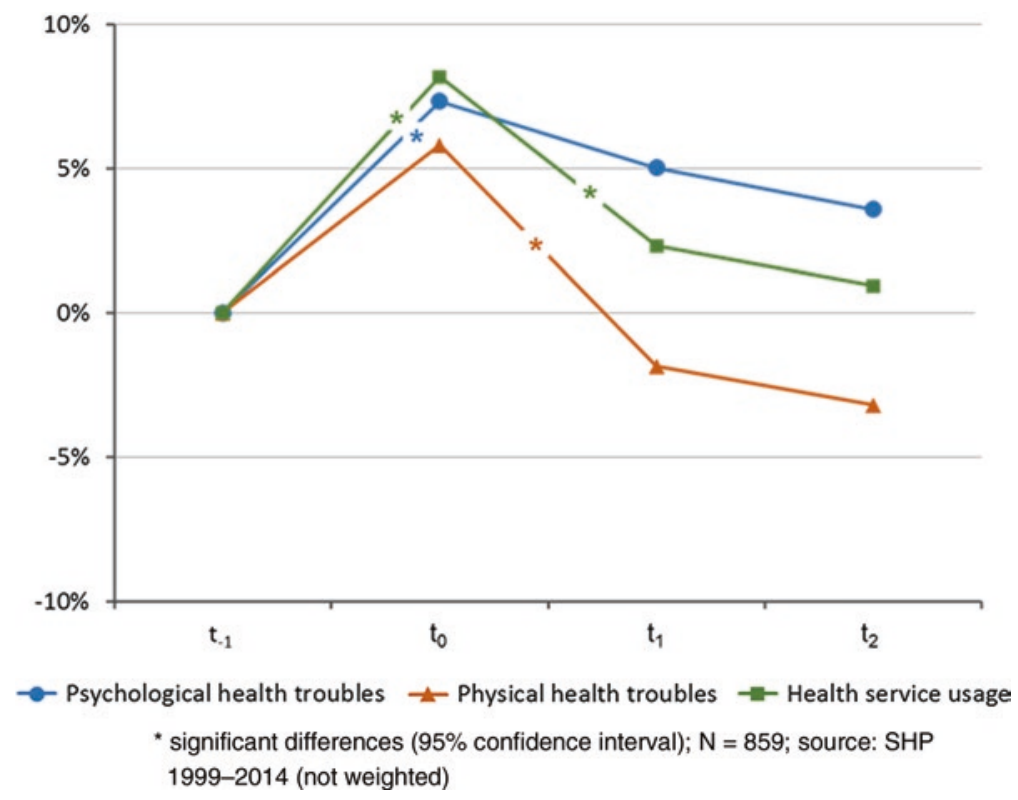

Fig. 7.1 Changes in health problems and the use of health-care services over four years (in percentages of levels before the subjectively perceived deterioration of health)

\section{Factors Influencing the Household's Welfare Position}

The multinomial logistic regression modeling procedure analyzes the effects of a breadwinner's deterioration of health on the household's welfare position. To empirically substantiate the relevance of the breadwinner function in sole-earner households by means of an exploratory group comparison between two types of households, we estimate two logistic models: one for "sole-earner households" (i.e., households with a breadwinner who contributes $80 \%$ or more to the household's income) and another for the "multiple-earner households" (i.e., households where co-earning members contribute between 40 and $80 \%$ to the household's income). The multivariate analysis serves to test the postulated effects of the independent variables $\left(\mathrm{H}_{1}\right.$ to $\left.\mathrm{H}_{9}\right)$ on the probability of the dependent categorical variable "household welfare position" (i.e., the three categories: remaining stable, ascent or descent in welfare position) following the breadwinner's deterioration in health. A stable welfare position was the reference category; the estimated coefficients of the households in the other two positions (ascent or descent in welfare position) are interpreted on the basis of this reference category.

Table 7.2 provides the estimated results of the multinomial regression with respect to ascent and descent of household welfare position as the result of a deterioration of health in the household. The first model (sole-earner household) tests the extent to which a change in the breadwinner's psychological and physical health 


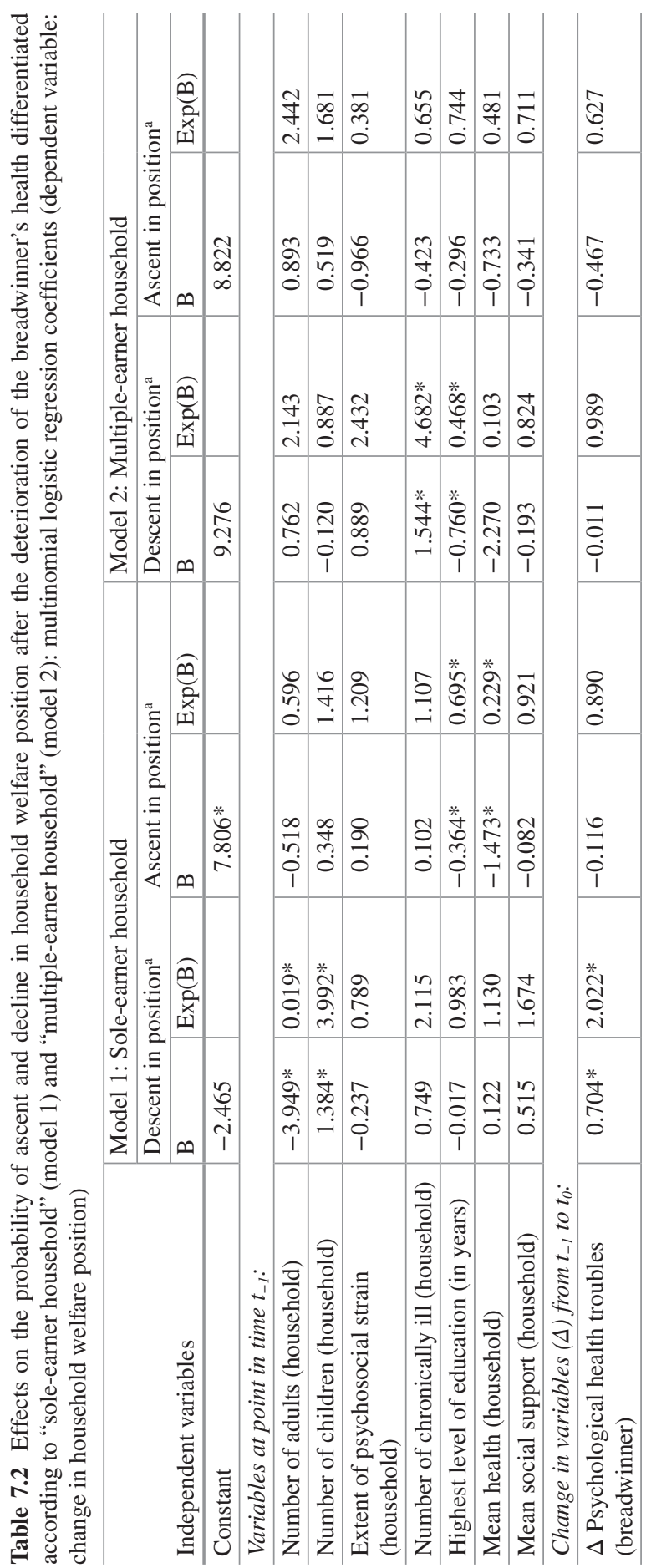




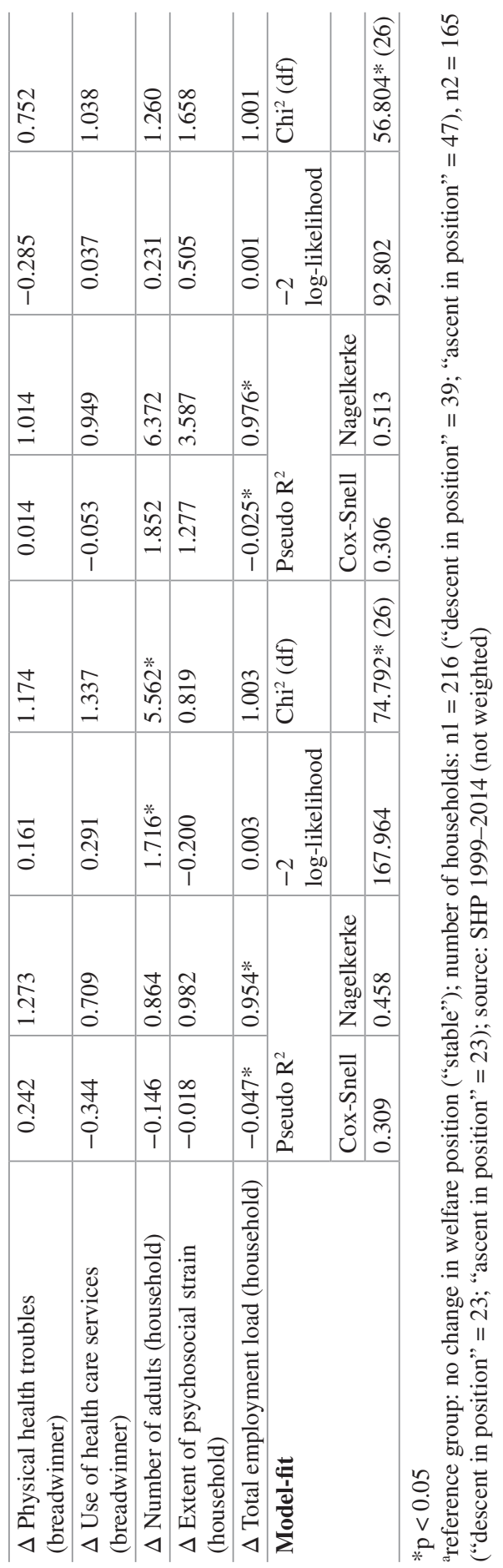


as well as the use of health-care services after deterioration of health affect the probability of descent in household welfare position. An important finding is contrary to the postulated effects: only the increase of psychological strain augments the risk of descent in household welfare position. The changes in the health-related variables following the deterioration of a co-earner's health, however, are not able to explain a change in the household's welfare position. Thus, the first hypothesis $\left(\mathrm{H}_{1}\right)$ can only be partly confirmed.

The relationship between the demographic- and resource-specific household characteristics before the breadwinner's health deteriorated and the likelihood of a change in the household's welfare position is revealed in Table 7.2. In sole-earner households a larger number of adults in the household considerably reduces the risk of descent, whereas a greater number of children in the household increases the risk of descent. These results confirm the second and the third hypotheses. In addition, the increase in the number of adults in a household supports an ascent in household welfare position. The risk of descent, however, is not significantly reduced. Therefore, hypothesis 4 must be rejected. In multiple-earner households, none of the demographic variables (number of adults in the household, number of children in the household, and change of number of adults in the household) exerts an influence on the probability of change in household welfare.

Hypotheses 5 and 6 must be rejected, because neither the number of chronically ill household members nor the extent of psychosocial strain in the household are found to exert an influence on the probability of change in household welfare. For multiple-earner households, the risk of descent in welfare position increases significantly with a growing number of chronically ill members in the household. When the effect of resource-specific factors is integrated into the analysis, households with members with higher educational levels tend to show greater stability in welfare position than those with lower educational levels. Both the likelihood of soleearner households ascending in welfare position and the risk of multiple-earner households descending in welfare position decreases. A higher average health status in the household seems to support stability and also lower the risk of ascent in welfare position. Contrary to our expectations, however, the average social support on the household level has no effect on the probability of a change in household welfare position. The seventh hypothesis may thus be rejected.

A change in psychosocial strain in the household has no significant effect on a change in household welfare position. An increase in the household's total employment load reduces the risk of descent in welfare position for both types of households. Hypothesis 8 may thus be rejected; whilst hypothesis 9 may be accepted.

\section{Discussion and Conclusion}

This contribution dealt with the relationship between a household breadwinner's health deterioration and the change in the household's welfare (operationalized by three welfare positions). From a life course perspective, there is, overall, empirical 
evidence that a deterioration in health not only affects individual modes of dealing with everyday activities but also the household's complex structure of roles and positions. In this regard, there is a clear association between the deterioration of the breadwinner's psychological health troubles in sole-earner households and the risk of a decline in household welfare. In contrast, the deterioration of a breadwinner's physical health troubles has no effect on the household's welfare in both household types.

In agreement with previous research (see Chen and Korinek 2010; Jenkins 2000), our findings show that while a greater number of adults in a household lowers the risk of a household of experiencing a decline in welfare, a greater number of children considerably increases this risk. Moreover, our analysis shows that the average health status in a sole-earner household tends to exert a stabilizing effect on the household's welfare following the deterioration of the breadwinner's health. Not only risk but also protective factors come into play and contribute to explaining the change of a household's welfare: both demographic factors and an increase in the overall employment load clearly lower the risk of the household to experience a decline in welfare. As such, the results suggest that in order to compensate for anticipated losses in employment or income due to the deterioration of a breadwinner's health, other household members activate their potential income generation capabilities by taking employment or increasing their employment loads.

Our findings support the thesis that the increase in psychological health troubles of the breadwinner (in sole-earner households) and the demographic and resourcespecific factors of the household are relevant for explaining the change of the household's welfare position as a result of a deterioration of the breadwinner's health. The analysis further substantiates empirically that demographic and resource-specific household factors (e.g., psychosocial strain) vary in relevance, depending on the organization of the provider status amongst the household members. In this regard, the comparison of the sole-earner and multiple-earner households reveals striking differences: in multiple-earner households, neither the type of illness nor demographic factors (e.g., number of adults or children in the household) are relevant regarding its change in welfare position. Moreover, other household-related factors are more important, such as the number of chronically ill household members.

The results further suggest that not all of the household-related characteristics studied here are associated with change in household welfare position. Rather, it is the interaction of the provider status amongst the household members (e.g., sole-earner or multiple-earner household) and household composition that contribute to explaining to some extent the change in household welfare position. Further research that explores the effects of changes in a household member's health more deeply would be highly desirable: at the household level, it would be important to study the effects of health deterioration of members with different roles regarding income contribution in households ranging from the traditional sole-earner household to the modern dual-earner household. Therewith, more knowledge about the influence of position and role constellations of the household members on health-specific mechanisms and their effects on household welfare could be generated. 


\section{References}

Allanson, P., Gerdtham, U.-G., \& Petrie, D. (2010). Longitudinal analysis of income-related health inequality. Journal of Health Economics, 29(1), 78-86.

Blood, R. O., \& Wolfe, D. M. (1960). Husbands and wives: The dynamics of married living. New York: Free Press.

Budowski, M., Knobloch, U., \& Nollert, M. (Eds.). (2016). Unbezahlt und dennoch Arbeit. Zürich: Seismo.

Callens, M., \& Croux, C. (2009). Poverty dynamics in Europe: A multilevel recurrent discrete-time hazard analysis. International Sociology, 24(3), 368-396.

Casimir, G. J., \& Tobi, H. (2011). Defining and using the concept of household: A systematic review. International Journal of Consumer Studies, 35, 498-506.

Chen, F., \& Korinek, K. (2010). Family life course transitions and rural household economy during China's market reform. Demography, 47(4), 963-987.

Connolly, S., O'Reilly, D., \& Rosato, M. (2007). Increasing inequalities in health: Is it an artefact caused by the selective movement of people? Social Science \& Medicine, 64(10), 2008-2015.

Daly, M. (2011). What adult worker model? A critical look at recent social policy reform in Europe from a gender and family perspective. Social Politics, 18(1), 1-23.

Dragano, N., \& Siegrist, J. (2009). Die Lebenslaufperspektive gesundheitlicher Ungleichheit: Konzepte und Forschungsergebnisse. In M. Richter \& K. Hurrelmann (Eds.), Gesundheitliche Ungleichheit. Grundlagen, Probleme, Perspektiven (2nd ed., pp. 181-194). Wiesbaden: VS Verlag für Sozialwissenschaften.

Egner, E. (1976). Der Haushalt. Eine Darstellung seiner volkswirtschaftlichen Gestalt. Berlin: Duncker und Humblot.

Erhart, M., Wille, N., \& Ravens-Sieberer, U. (2009). Die Messung der subjektiven Gesundheit: Stand der Forschung und Herausforderungen. In M. Richter \& K. Hurrelmann (Eds.), Gesundheitliche Ungleichheit. Grundlagen, Probleme, Perspektiven (2nd ed., pp. 335-352). Wiebaden: VS Verlag für Sozialwissenschaften.

Filipp, S.-H., \& Aymanns, P. (2009). Kritische Lebensereignisse und Lebenskrisen. Vom Umgang mit den Schattenseiten des Lebens. Stuttgart: Kohlhammer.

Galler, H. P., \& Ott, N. (1993). Empirische Haushaltsforschung. Erhebungskonzepte und Analyseansätze angesichts neuer Lebensformen. Frankfurt/New York: Campus Verlag.

Gordon, D., \& Spicker, P. (1999). The international glossary on poverty. London/New York: Zed Books.

Halleröd, B., \& Gustafsson, J.-E. (2011). A longitudinal analysis of the relationship between changes in socio-economic status and changes in health. Social Science \& Medicine, 72(1), $116-123$.

Hurrelmann, K. (2006). Gesundheitssoziologie. Eine Einführung in sozialwissenschaftliche Theorien von Krankheitsprävention und Gesundheitsförderung (6th ed.). Weinheim: Juventa.

Jenkins, S. P. (2000). Modelling household income dynamics. Journal of Population Economics, $13(4), 529-567$.

Jungbauer-Gans, M., \& Gross, C. (2009). Erklärungsansätze sozial differenzierter Gesundheitschancen. In M. Richter \& K. Hurrelmann (Eds.), Gesundheitliche Ungleichheit. Grundlagen, Probleme, Perspektiven (2nd ed., pp. 77-98). Wiesbaden: VS Verlag für Sozialwissenschaften.

Keck, M., \& Sakdapolrak, P. (2013). What is social resilience? Lessons learned and ways forward. Erdkunde, 67(1), 5-19.

Levy, R. (1996). Zur Institutionalisierung von Lebensläufen. Ein theoretischer Bezugsrahmen. In J. Behrens \& W. Voges (Eds.), Kritische Übergänge. Statuspassagen und sozialpolitische Institutionalisierung (pp. 73-113). Frankfurt am Main: Campus. 
Mackenbach, J. P. (2006). Health inequalities: Europe in profile. London: Departement of Health.

Rueda, S., Chambers, L., Wilson, M., Mustard, C., Rourke, S. B., Bayoumi, A., et al. (2012). Association of returning to work with better health in working-aged adults: A systematic review. American Journal of Public Health, 102(3), 541-556.

Sauerborn, R., Adams, A. T., \& Hien, M. (1996). Household strategies to cope with the economic costs of illness. Social Science \& Medicine, 43(3), 291-301.

Steinkamp, G. (1999). Soziale Ungleichheit in Mortalität und Morbidität. In W. Schlicht \& H. H. Dickhuth (Eds.), Gesundheit für alle: Fiktion oder Realität? (pp. 101-154). Stuttgart/New York: Schattauer.

Thébaud, S. (2010). Masculinity, bargaining, and breadwinning: Understanding men's housework in the cultural context of paid work. Gender and Society, 24(3), 330-354.

Tillmann, R., \& Budowski, M. (2006). La pauvreté persistante: un phénomène de classe, de cumul de désavantages ou d'individualisation? Revue suisse de sociologie, 32(1), 329-348.

Townsend, P. (1979). Poverty in the United Kingdom. London: Penguin.

Open Access This chapter is licensed under the terms of the Creative Commons Attribution 4.0 International License (http://creativecommons.org/licenses/by/4.0/), which permits use, sharing, adaptation, distribution and reproduction in any medium or format, as long as you give appropriate credit to the original author(s) and the source, provide a link to the Creative Commons license and indicate if changes were made.

The images or other third party material in this chapter are included in the chapter's Creative Commons license, unless indicated otherwise in a credit line to the material. If material is not included in the chapter's Creative Commons license and your intended use is not permitted by statutory regulation or exceeds the permitted use, you will need to obtain permission directly from the copyright holder.

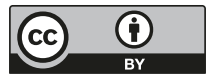

